\title{
Errata
}

\section{Erratum: Li et al., "The DNA Repair-Associated Protein Gadd45 $\gamma$ Regulates the Temporal Coding of Immediate Early Gene Expression within the Prelimbic Prefrontal Cortex and Is Required for the Consolidation of Associative Fear Memory"}

In the article "The DNA Repair-Associated Protein Gadd45 $\gamma$ Regulates the Temporal Coding of Immediate Early Gene Expression within the Prelimbic Prefrontal Cortex and Is Required for the Consolidation of Associative Fear Memory" by Xiang Li, Paul R. Marshall, Laura J. Leighton, Esmi L. Zajaczkowski, Ziqi Wang, Sachithrani U. Madugalle, Jiayu Yin, Timothy W. Bredy, and Wei Wei, which appeared on pages 970-983 of the February 6, 2019 issue, some of the references on page 971, first full paragraph, appeared incorrectly. Beginning with the third sentence, the references "Baker-Andresen et al., 2013", "Li et al., 2014", and "Miller et al., 2010; Baker-Andresen et al., 2013; Li et al., 2014" should appear as “Savell et al., 2016”, "Rudenko et al., 2013”, and "Massart et al., 2015; Wright et al., 2015”, respectively. In addition, the following references should be added to the reference list:

\section{References}

Massart R, Barnea R, Dikshtein Y, Suderman M, Meir O, Hallett M, Kennedy P, Nestler EJ, Szyf M, Yadid G (2015) Role of DNA methylation in the nucleus accumbens in incubation of cocaine craving. J Neurosci 35:8042-8058. 10.1523/JNEUROSCI.3053-14.2015

Savell KE, Gallus NV, Simon R, Brown JA, Revanna JS, Osborn MK, Song EY, O’Malley JJ, Stackhouse CT, Norvil A, Gowher H, Sweatt JD, Day JJ (2016) Extra-coding RNAs regulate neuronal DNA methylation dynamics. Nat Commun 7:12091. 10.1038/ncomms12091

Wright KN, Hollis F, Duclot F, Dossat AM, Strong CE, Francis TC, Mercer R, Feng J, Dietz DM, Lobo MK, Nestler EJ, Kabbaj M (2015) Methyl supplementation attenuates cocaine-seeking behaviors and cocaine-induced c-Fos activation in a DNA methylation-dependent manner. J Neurosci 35:8948-8958. 10.1523/JNEUROSCI.5227-14.2015

These errors do not affect the conclusions of the article. The article has been corrected online.

DOI: 10.1523/JNEUROSCI.0577-19.2019

\section{Erratum: Lee et al., "Electrophysiological Signatures of Spatial Boundaries in the Human Subiculum"}

In the article "Electrophysiological Signatures of Spatial Boundaries in the Human Subiculum" by Sang Ah Lee, Jonathan F. Miller, Andrew J. Watrous, Michael R. Sperling, Ashwini Sharan, Gregory A. Worrell, Brent M. Berry, Joshua P. Aronson, Kathryn A. Davis, Robert E. Gross, Bradley Lega, Sameer Sheth, Sandhitsu R. Das, Joel M. Stein, Richard Gorniak, Daniel S. Rizzuto, and Joshua Jacobs, which appeared on pages 3265-3272 of the March 28, 2018 issue, due to a production error, the fifth word of the Discussion section on page 3269 should be "LFP", rather than "LTP". This error does not affect the conclusions of the paper and the online version has been corrected.

DOI: $10.1523 / J N E U R O S C I .0579-19.2019$ 